\title{
Reflective Teaching or Teacher Authenticity: An Investigation of the Self
}

\author{
Amin Shahini \\ Department of English Language Teaching, Golestan Scientific and Research Branch, Islamic Azad University, Gorgan, Iran
}

\section{Email address:}

shahiniamin@gmail.com

\section{To cite this article:}

Amin Shahini. Reflective Teaching or Teacher Authenticity: An Investigation of the Self. Science Journal of Education. Vol. 3, No. 5, 2015, pp. 100-106. doi: 10.11648/j.sjedu.20150305.11

\begin{abstract}
In the present paper, different views of reflective practice in literature are presented. It is argued that reflective practices are not a matter of casual reflection and taking others-directed decisions on courses of actions but are rather a systematic, critical and holistic approach to the appraisal of what teachers do in class. We will go on further to introduce a new concept of authenticity heavily influenced by the concept of critical reflection and will argue that teachers state of idealism is when they can obtain the best understanding of the self and the world around themselves. By getting to the self they set themselves free from the confinements of imitating the herd and consequently can become the transformers of the educational and social circles all with the aim of promoting the personal and social values of the learners who have an undeniable role in the future of any society. Later in the article, transformative learning theory and its four strands of thought as key issues in the process of teacher authentication are proposed.
\end{abstract}

Keywords: Reflective Teaching, Authentic Teaching, Transformation

\section{Introduction}

Literature is replete with studies that have delved into the concept of reflective teaching and practice in the past decades (e.g., Akbari, 2007; Clark, 2006; Cruickshank \& Applegate, 1981; Farrell, 2007, 2012; Fendler, 2003; Kumaravadivelu, 2003; Ryan \& Ryan, 2013; Shotte, 2008). All these studies have one point in common and it is the fact that pedagogues have to break their stereotype as a teaching machine and start to reflect upon their performance in the class. Of course, by reflection they mean a systematic and critical appraisal of the steps that teachers have taken or are to take in the class and not an ad hoc one. Roberts (1998) refers to this thoughtful systematicity as the "strong version" of reflection and discusses it against its weak version where teaching is "no more than thoughtful practice where teachers sometimes informally evaluate various aspects of their professional expertise" (p. 8). However, reflective teaching is not an end in itself and should only embrace part of a more in-depth process called authentic teaching. The concept of authentic teaching rooted from critical reflection proposes that the end point of teachers' professional career should be the state where they can obtain the best understanding of the self and the world around themselves. In this view of authenticity in teaching, teachers are transformers who by being aware of the self, seek to change and promote the personal and social values of the learners and consequently that of the society. In the present paper, an attempt is made to uncover the new concept of authentic teaching by an in-depth investigation of reflective practice as its precursor and then try to see its links to the broader context of critical pedagogy.

Long before Robert's (1998) weak version of reflective teaching which he believed even to have a detrimental effect on the process of education, Dewey (1933) put forth the notion of routine action (put against reflective action) and characterized it as guided by impulse, tradition, and authority. Dewey maintained that in any educational setting, there is always a collective code in which preplanned solutions to any upcoming problem is devised and defined. This code is squarely dominating and as long as things proceed successfully, no change is made and no alternatives are sought for (Zeichner \& Liston, 1996). What is evident in Dewey's argument is that he is against stereotyping teachers as agents of others who are destined to opt from among a limited number of options which are usually the most common ones in a given situation (Farrell, 2012). Kumaravadivelu (2003) has a grip of the issue from the behavioral psychology perspective:

The basic tenets of the concept of teachers as technicians 
can be partly traced to the behavioral school of psychology that emphasized the importance of empirical verification. In the behavioral tradition, the primary focus of teaching and teacher education is content knowledge that consisted mostly of a verified and verifiable set of facts and clearly articulated rules. Content knowledge is broken into easily manageable discrete items and presented to the teacher in what might be called teacher-proof packages. Teachers and their teaching methods are not considered very important because their effectiveness cannot be empirically proved beyond doubt. Therefore, teacher education programs concentrate more on the education part than on the teacher part. Such a view came to be known as the technicist view of teaching and teacher education (p. 8).

Kumaravadivelu argues against spoon feeding teachers in "manageable discrete items" which he calls "teacher-proof", asserting that in this view teachers' role would be diminished to that of a "technicist" who is at the service of decision makers. In a similar vein, Greene (1986) pointed out that reflection is "holistic" in terms of facing and responding to problems and does not consist of a series of instructions to be followed by teachers. It is a process beyond the logical and rational analyses and entails intuition, knowledge of the self and passion and cannot be packaged as a set of prefabricated techniques.

\section{Definitions and Models of Reflective Practice}

Since the concept of reflective teaching is an elusive one (Roberts, 1998), scholars offered various definitions each pinning down one aspect of the concept. For example, Shotte (2008) defines reflective teaching as a cyclical and spiraling process in which teachers monitor, evaluate and revise their own practice continuously. In Cruickshank and Applegate's (1981) view, reflective teaching is a process that "helps teachers to think about what happened, why it happened, and what else could have been done to reach their goals" (p. 553)

Elsewhere, Reid (1993, cited in Reece \& Walker, 2007, p. 421) states "reflective practice is a process of reviewing an experience from practice" while Zeichner and Liston (1996) argue for critical reflection-issues of linking teaching to the society where teachers can become agents of change of culture, history, etc. Reid's definition of reflective teaching is closely related with Kolb's model (1984) that considered the role of experience, observation, conceptualization, and experimentation as the four cycles of reflective practice. He stated that the cycle may be started at any of the four stages and the sequence of the stages in the cycle is important. Following that, Gibbs (1988) completed Kolb's model with a simpler way of presentation. According to Gibbs' model, in the reflective cycle, we start with the description: this is merely recall and is the lowest level of learning in the cognitive domain. However, the remaining five steps cause us to think more deeply about the issues and can lead to very valuable insights. Figure 1 illustrates his model in detail:

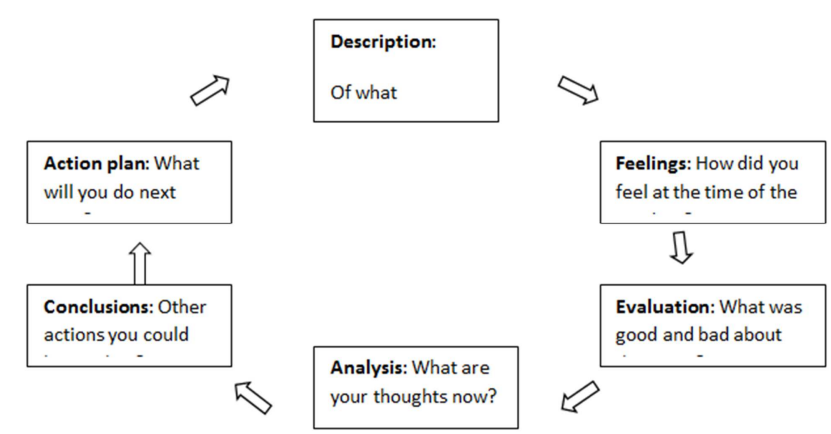

Figure 1. Gibbs (1988) reflective cycle.

\section{Authentic Reflection}

However, what lies at the heart of each of these models and their approach to reflection is something beyond the simple reflection and the question of its timely occurrence. The "Self" is what Cranton (2001) argues to lie at the center of any reflective practice - an entity that makes reflection authentic. He defines the Self as a person's "basic nature, preferences, values, and the power of past experiences" (p. 7). What he solemnly follows in his discussion is to maintain the fact that teachers can become authentic by making informed decisions based on the understanding that who they actually are. In this way, they can empower themselves which in turn can help them, through their sound choices, free themselves from "the constraints of uncritically assimilated values, assumptions, and social norms [of] the herd" (p. 7). By the social norms of the heard he meant the blind imitation of others without understanding, discovering, and evaluating the self values. This process is referred to as Self Deconstruction which maintains that teachers should come to an understanding that for understanding others one needs to break the Self through the analysis of the values and beliefs. He also noted that experience plays a determining role in the process of Self deconstruction in that through experience teachers make and shape their understanding of the world. He claims "the way we make meaning out of experiences determines our habitual expectations and our habits of mind - our assumptions, beliefs, values, and perspectives" (p. 15).

Cranton (2001) encouraged teachers to come one stage above the outward reflection of the teaching process and instead reflect upon the within and upon the relationship between their personal value system and their culture in a bid to better understand their own worldview. According to this view this process is a transformative one which requires teachers to look out through looking in (Kalantzis \& Cope, 2008; Leonardo, 2004). Teachers reconstruct the Self by being genuine and true. They will contribute to this aim by practicing the motto "Self as teacher, teacher as Self". The realization of this claim, however, has not been noticeably observed in major approaches of language teaching (for example, those based on behavioral psychology, humanism, John Dewey's functionalism, Kolb's experiential learning, or Gardner's theory of multiple intelligences in the classroom) where they directed an unduly devotion of attention to the 
"teacher without" rather that the "teacher within". What these learning theories and models share is shedding light on the otherness rather than the Self.

Here, the question open to investigation is concerned with the nature of reflection that we as scholars wish to know and practice. Should reflective practice be conceived of as an uncritical and informal approach to evaluating classroom practices as the weak version type of reflection like that of Roberts' (1998) where teachers pay scant attention to their practices? Or should it be accounted for as a holistic and non-discrete practice, a position taken by Kumaravadivelu (2003) and Greene (1986)? Or even to complicate the issue further, as something that Cranton (2001) dubbed deconstructing the Self? This paper seeks answer to this question in a bid to find out a true meaning for authentic reflection.

\section{Authentic Teacher and Transformative Learning Theory (TLT)}

TLT is an adult education-based theory that suggests ways in which adults make meaning of their lives (Mezirow, 1991, 1995, 1996, 2006; Cranton, 1994). This theory is by no means as shallow as the content or even process of learning but rather it accounts for an in-depth approach towards learning. Wallace (1991) has a clear definition of TLT:

It looks at "deep learning," and examines what it takes for adults to move from a limited knowledge of knowing what they know without questioning (usually from their cultures, families, organizations and society). It looks at what mechanisms are required for adults to identify, assess and evaluate alternative sources of information, often sources that may looks at how adults can identify, assess and evaluate new information, and in some cases, reframe their worldview through the incorporation of new knowledge or information into their world-view or belief system.

The concept of authentic teacher realized through the "incorporation of new knowledge or information into their world-view or belief system" and the deep reflection on personal values and the Self was in part heavily derived from the deliberations of Mezirow $(1991,2000)$ on the theory of transformative learning through which one can reach potential ways to perceiving how human changes his beliefs attitudes and values. TLT is mainly concerned with becoming "critically aware of one's own tacit assumptions and expectations and those of others and assessing their relevance for making an interpretation" (Mezirow, 2000, p. 4).

Drawing on the work of Mezirow and Cranton, teachers' better reflection of the Self and beliefs will lead to their authenticity which in its new version is defined as the "expression of one's genuine Self in the community and society (p. 8). This view of authenticity is in line with existentialist line of thinking which lends support to the concept of the aware Self as a thinking being with beliefs, hopes, fears, desires, the need to find a purpose, and a will that can determine one's actions (p. 8).
What an existential approach seeks is the investigation of individuals who have come to an understanding of their existence as a self-aware entity, the knowledge of which has been gained through their own experiences of their situations in life. Authenticity, in the existentialist view, is the best expression of a worthwhile life. Individuals are expected to face up to their challenges and prosper in the process of dealing with them (Taylor, 2006).

Authentic teachers as transformative individuals do not view teaching as the way instrumentally-oriented teachers do (Dirkx, 1998), but rather have a different perspective in mind, putting more reflection on the in-depth processes and aims of learning having obtained a well understanding of the Self.

Regarding TLT research and theory, Clark (1993) proposed four strands of thought as key issues in the process of teacher authentication:

\subsection{Transformation 1: Consciousness Raising in Teachers}

The concept of consciousness raising is important in having a better grasp of transformative learning in that it directs teachers to an awareness that rises above the normal and typical concept of awareness (Taylor, 2008). Chaplin (1985, cited in Cranton, 1994) proposed a psychological definition of consciousness raising as "the process of developing self-knowledge and self-awareness" (p.133). This definition is in line with the pivotal process of transformative learning which is becoming aware and then contemplating of one's construction of meaning.

This view of transformation theory was advocated by Freire (1970). For Freire, adult education is not only dealt with teaching academic subjects but also should aim at fostering critical consciousness among individuals and groups. His work to a great deal is guided by a desire for political liberation and freedom from oppression (Glass, 2001). According to McLaren (2001), critical consciousness is a process in which learners are enabled to scrutinize, question, and act upon the social and political, cultural and economic contexts that influence and shape their lives. In the course of dialog and problematization, learners develop awareness of structures within their society that may be contributing to inequality and oppression. Based on Friere's view, an authentic teacher should help learners develop a deeper understanding of the ways in which these social structures shape and influence the way they think about themselves and the world. This process entails a reciprocal and dialectical action and reflection which are under the constant influence of each other.

Freire termed this process praxis through which he claimed teachers have the duty of growing the sense of liberation (from oppression) among learners by enabling them to critically reflect on their surrounding world in a bid to change it. For Freire, transformational learning is emancipatory and liberating at both personal and a social level. It provides teachers with a voice, with the ability to name the world, and in so doing, construct for themselves the meaning of the world. 


\subsection{Transformation 2: Promoting Critical Reflection in Teachers}

Mesirow (1991) is primarily concerned with the process of making meaning of one's experiences through reflection and critical-reflection. He sees critical reflection as follows:

Perhaps even more central to adult learning than elaborating established meaning schemes is the process of reflecting back on prior learning to determine whether what we have learned is justified under present circumstances. This is a crucial learning process egregiously ignored by learning theorists. (Mezirow, 1990, p. 5)

He maintains that such reflection on assumptions and presuppositions (particularly about oneself) leads to "transformative learning".

Perspective transformation is the process of becoming critically aware of how and why our presuppositions have come to constrain the way we perceive, understand, and feel about our world; of reformulating these assumptions to permit a more inclusive, discriminating, permeable and integrative perspective; and of making decisions or otherwise acting on these new understandings. More inclusive, discriminating permeable and integrative perspectives are superior perspectives that adults choose if they can because they are motivated to better understand the meaning of their experience. (Mezirow, 1990, p. 14)

In other words, teachers get closer to authenticity when they begin to re-evaluate their lives and to re-make them. This gives credence to the argument that teacher's authenticity is more of a matter of critical reflection than reflection. The state of critical reflection is achieved through a series of reflective and interrelated processes.

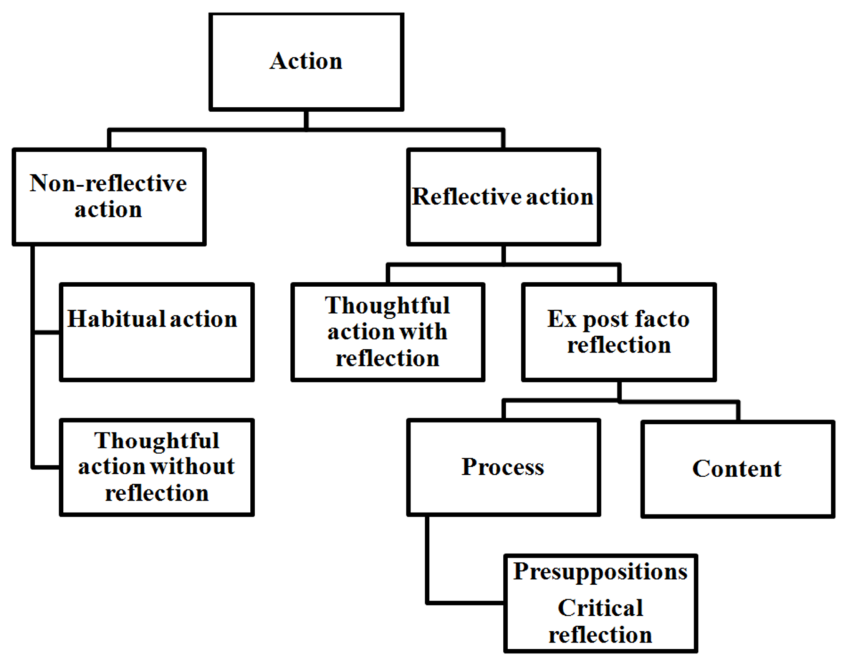

Figure 2. Ezirow's (1990) critical reflection model.

Reflective action is critical to assessment of assumptions and an integral part of decision making. Thoughtful action is also reflective but not the kind of reflection done as to critically examine our beliefs and values. Reflection in thoughtful action is about reassessing our actions to find about our deficits by raising the question: What is wrong with what I am doing? This inquiry is a fraction of a millisecond in the decision-making process. Reflection is therefore an inseparable part of any thoughtful action.

Ex post facto reflection, being a retrospection on prior learning, centers on assumptions about the content of the problem, the process or procedures followed in problem solving, or the presupposition which constitutes the foundation of a given problem. According to Mezirow, reflection on presuppositions is what is referred to as critical reflection. The following figure shows this hierarchy in detail:

According to this view, authentic teachers should critically reflect on their presuppositions in an attempt to find solutions to within-class problems - the problems that are at the same time not confined to class environment and are expandable to social circles. Authentic teachers should not only foster this within themselves, but also have to educate their learners to become critical reflectors who constantly evaluate and rebuild their understanding of their surrounding world and society.

Critical reflection, for Mezirow, takes precedence over whatever it was they set out to "learn" in the first place. Other contributors to the collection make clear that the overall project is necessarily politicized, as his indebtedness to Habermas and Freire indicates. While Freire seemed intent on developing a process of education consistent with his theory of human nature, Mezirow continues to focus on developing a comprehensive theory of adult learning. Like Freire, Mezirow views knowledge as something that is constructed by the individual in relation to others.

\subsection{Transformation 3: Teachers Development}

Unlike Mezirow's view of developmental perspective which is so implicit in his view of transformative learning, Larry Dolaz (1986) provides a central and organizing framework for understanding transformative learning as growth. Daloz sees our ability to make sense of our experience as related to the developmental movement of our lives. Movement into new developmental phases requires the adult learner to construct new meaning structures that help them perceive and make sense of their changing world. According to this view, teachers should put themselves in a constant process of change and growth. For example, one cannot keep the same view of the world and the self as he did in his youth. He has to grow his understanding of the self and his world view in an attempt to keep pace with the demands of his current point of life. This ongoing reconstruction of the self is never-ending and constitutes a core principle of educational authenticity. This view of transformation is heavily influenced by sociocultural mechanisms and relies on constructivist views of knowledge and learning.

Unlike Mezirow and Freire, Daloz is not mainly concerned with the rational and reflective practices but rather with intuitive and holistic processes.

\subsection{Transformation 4: Individuation of Teachers}

An authentic teacher in transformational education separates himself/ herself from the collective code and the 
prevalent norms of others and attempts to get to his/her within through the act of critical reflection and individuation. Through individuation and understanding of the Self, teachers can in turn reunite with others in a more authentic manner constantly comparing and evaluating their values with others - an essence to authenticity. Teachers, in this way, find a chance to volume up their voices and become the iconoclasts of the norms of the herd.

Jung (1921, cited in Mezirow, 1990) many years ago hypothesized that we are all members of a heard that are constantly getting distant from the collective and getting close to our Selves. This process of individuation incorporates a dialog with ourselves which eventually will lead to authenticity. In a way one can find similarities between critical reflection and the process of individuation but Dirkx (1998) saw individuation as a more unconscious process than critical reflection and referred to it as soulfulness.

\section{Discussion}

The picture that was sketched throughout the article was more of idealism than realism in developing an authentic teacher-someone who is perfectly reflective and transformative and is absolutely unaffected by intervening conditions. So, how is it possible to make this idealism closer to realism? What practices must be undertaken in educational settings in order to make this more than paying lip service to the merits of authentic teaching? What are the interventions in this regard?

Authentic teaching is closely interwoven with critical pedagogy (see Freire, 1972; Pennycook, 2002) in a postmethod era. Various controversial topics such as teacher's identity (see Beauchamp \& Thomas, 2009; Cochran-Smith, 2005), teacher's self-image (Kosslyn, Thomson, \& Ganis, 2006; Markus \& Ruvolvo, 1989; Paivio, 1985; Wenger, 1998), teacher's power (Wood \& Wood, 1984), teacher's voice (Kumaravadivelu, 2001) and other post-method fields of enquiry all are squarely linked with teacher authenticity. Therefore, it is right to claim that the concept of authentic teaching is a subcategory of the post-method era. However, as Akbari (2008) has truly pointed out post-method proponents put an end to the method era with promise of turning the tables in favor of teachers and their needs, lacks and wants. In fact this idealism didn't realize to realism and teachers have continued to be suppressed by policy-making mechanisms which have up to now muffled teachers' voices. Authentic teaching is not an exception in this regard and has been under the detrimental and dominant mechanisms of the era. One of the factors that have had a preventive effect on authentic teacher development has been the "parameter of possibility" which Kumaravadivelu defined as the "the sociopolitical consciousness that students bring with them to the classroom" (2006, p. 59). The parameter or pedagogy of possibility (among the other two parameters of particularity and practicality) is derived from the Frierean critical pedagogy which claims that education should be employed to sustain the political and social inequalities (Kumaravadivelu, 2003). Taking a step towards removing the sociopolitical injustice and the promotion of individual identity seems alluring as it is undoubtedly a perfect leap towards teacher authenticity. However, the question raised here is how should this social or political awareness be raised? If learners are to undergo transformative education with the aim of expanding it to the social and political world, a necessary prerequisite to that would be a sound knowledge and awareness of the political and social ambience of that milieu. This is while such topics are among the redlines and are strongly banned by top decision makers, a decision which is mirrored to in-service and preservice teachers by supervisors and managers or through teachers training courses. Therefore, teachers don't find the opportunity to delve into these topics in a bid to raise learners' awareness. Even if they do by defying the odds, fear of the consequences wouldn't allow it to be a systematic and beneficial regularity in class. As a principle of critical pedagogy, awareness of the sociopolitical ambience helps learners to become socially and politically transformative. An authentic teacher should take a step in that direction. Moreover, an authentic teacher should be capable of developing a sense of libratory autonomy (Benson \& Voller, 1997) inside their learners that makes them critical thinkers in order to realize their potentials. Kumaravadivelu (2003) argued that libratory autonomy "goes much further than academic autonomy by actively seeking to help learners recognize sociopolitical impediments placed in their paths to progress, and by providing them with the intellectual tools necessary to overcome them" (p. 141). What rises out of this argument is that although the sociopolitical status of a country might make it costly and insecure for teachers to foster and direct learners to stand against the inequalities and bias, they should germinate the seeds of libratory autonomy inside learners in an attempt to transform the dominating status quo of the milieu in the long run.

Everything in today's world has been at least in one aspect affected by the political stance of that country and education has been no exception. We can claim that education tightly bonds with the sociopolitical atmosphere of a given country; so does authentic teaching. In totalitarian regimes where libratory autonomy has no place in the macro levels of education, the seeds of authentic teaching are nipped in the bud whereas in liberal societies the situation is much better though not ideal. That is to say, the practicality of authentic teaching is in close tie with the policy making of statesmen who normally have inadequate understanding of education let alone the authentic one! It seems that if any change is to be made, it should be made in the views that are held by policymakers. Here education should be saved for it to be a savior. It should be amended from outside rather than inside, revisited by top policymakers rather than practitioners and teachers. In a nutshell, it should be authentic. However, it is a sweet dream that is still too far away from reality. 


\section{References}

[1] Akbari, R. (2008). Postmethod discourse and practice. TESOL Quarterly, 42 (4), 641-652.

[2] Akbari, R. (2007). Reflections on reflection: a critical appraisal of reflective practices in L2 teacher education. System, 35, 192-207.

[3] Beauchamp, C. \& Thomas, L. (2009). Understanding teacher identity: An overview of issues in the literature and implications for teacher education. Cambridge Journal of Education, 39 (2), 175-189.

[4] Benson, P., Voller, P. (1997). Introduction: autonomy and independence in language learning, In: P. Benson \& P. Voller (Eds.), Autonomy and independence in language learning (pp. 1-12). Longman: London.

[5] Clark, M. C. (1993). Transformational learning, In: S. B. Merriam (Ed.), An update on adult learning theory (pp. 4757). Jossey-Bass: San Francisco.

[6] Clarke, A. (2006). The nature and substance of cooperating teacher reflection. Teaching and Teacher Education, 22, 910921.

[7] Cochran-Smith, M. (2005). The new teacher education: for better or for worse? Educational Researcher 34 (7), 3-17.

[8] Cranton, P. (2001). Becoming an authentic teacher in higher education. Malabar: Krieger Publishing Company.

[9] Cranton, P. (1994). Understanding and promoting transformative learning: A guide for educators of adults. San Francisco: Jossey Bass.

[10] Cruickshank, D. R., Applegate, J. (1981). Reflective teaching as a strategy for teacher growth. Educational Leadership, 38 (7), 553-4.

[11] Dirx, J. M. (1998). Transformative learning theory in the practice of adult education: An overview. PAACE Journal of Lifelong Learning, 7, 1-14.

[12] Daloz, L. A. (1999). Mentor: Guiding the journey of adult learners. San Francisco CA: Jossey-Bass.

[13] Farrell, T. S. C. (2012). Reflecting on Reflective Practice: (Re)Visiting Dewey and Schön. TESOL Journal, 3 (1), 7-16.

[14] Farrell, T. S. C. (2007). Reflective language teaching: From research to practice. New York: Continuum.

[15] Fendler, L. (2003). Teacher reflection in a hall of mirrors: Historical influences and political reverberations. Educational Researcher 32, 16-25.

[16] Freire, P. (1970). Pedagogy of the oppressed. NY: Herder and Herder.

[17] Freire, P. (1972). Education: Domestication or liberation? Quarterly Review of Education 2 (2), 193-202.

[18] Gibbs, G. (1988). Learning by Doing: A guide to teaching and learning methods. London: Further Education Unit.

[19] Giroux, H. A. (1988). Literacy and pedagogy of voice and political empowerment. Educational Theory, 38, 1, 61-75
[20] Glass, D. (2001). On Paulo Freire's philosophy of praxis and the foundations of liberation education. Educational Researcher, 30, 2, 15-25.

[21] Greene, M. (1986). Reflection and passion in teaching. Journal of Curriculum and Supervision, 2(1), 68-81.

[22] Jamieson, D. W., Thomas, K, W. (1974). Power and conflict in the classroom. The Journal of Applied Behavioral Science, 10, $3,321-336$.

[23] Kalantzis, M., \& Cope, B. (2008). New Learning: Elements of a Science of Education. Cambridge: Cambridge University Press.

[24] Kolb, D. A. (1984). Experiential learning: Experience as a source of learning and development. Englewood Cliffs NJ, Prentice Hall.

[25] Kosslyn, S. M., Thompson, W. L., Ganis, G. (2006). Mental imagery doesn't work like that. Behavioral and Brain Sciences, $25,198-200$.

[26] Kumaravadivelu, B. (2006). Understanding language teaching: From method to post method. NJ: Lawrence Erlbaum Associates, Publishers.

[27] Kumaravadivelu, B. (2003). Beyond methods: Macrostrategies for language teaching. London: Yale University Press.

[28] Kumaravadivelu, B. (2001). Towards a postmethod pedogogy. TESOL Quarterly, 35 (4), 537-560.

[29] Leonardo, Z. (2004). Critical social theory and transformative knowledge: The functions of criticism in quality education. Educational Researcher, 33(6), 11-18.

[30] McLaren, P. (2001). Che Guevara, Paulo Freire, and the politics of hope: Reclaiming critical pedagogy. Cultural Studies: Critical Methodologies 1 (1), 108-131.

[31] Mezirow, J. (2000). Learning to think like an adult: Core concepts of transformation theory. In J. Mezirow (Ed.), Learning as transformation: Critical perspectives on a theory in progress (pp. 3-33). San Francisco: Jossey-Bass.

[32] Mezirow, J. (1996). Contemporary paradigms of learning. Adult Education Quarterly, 46 (3), 158-172.

[33] Mezirow, J. (1995). Transformation theory of adult learning. In M. R. Welton (Ed.), Defense of the life world (pp. 39-70). NY: Sunny Press.

[34] Mezirow, J. (1991). Transformative dimensions of adult learning. San Francisco: Jossey-Bass.

[35] Mezirow, J. (1990). How critical reflection triggers transformative learning. In J. Mezirow (Ed.), Fostering critical reflection in adulthood: A guide to transformative and emancipatory learning (pp.1-20). San Francisco CA, JosseyBass Publishers.

[36] Paivio, A. (1985). Cognitive and motivational functions of imagery in human performance. Canadian Journal of Applied Sport Sciences, 10(4), 225-285.

[37] Pennycook, A. (1995). English in the world/ The world in English. In J. W. Tollefson (Ed.), Power and inequality in language education (pp. 34-58). Cambridge: Cambridge University Press. 
[38] Roberts, J. (1998). Language teacher education. London: Arnold.

[39] Reece, I., Walker, S. (2007). Teaching, training, and learning: a practical guide $\left(6^{\text {th }}\right.$ ed.). London: Business Education Publishers Ltd.

[40] Ryan, M. E. \& Ryan, M. (2013). Theorising a model for teaching and assessing reflective learning in higher education. Higher Education Research and Development, 5 (2), 4-20.

[41] Shotte, G. (2008). Reflecting teaching: Some reflections. Middlesex University Occasional Papers in Education \& Lifelong Learning 2 (1), 5-23.

[42] Taylor, E. W. (2008). Transformative learning theory. In S. B. Merriam (Ed.), Third update on adult learning theory (pp.517). San Francisco: Jossey-Bass.

[43] Taylor, E. W. (2006). The challenge of teaching for change. In
E. W. Taylor (Ed.), Teaching for change: fostering transformative learning in the classroom: New directions in adult and continuing education (pp. 23-45). San Francisco: Jossey-Bass.

[44] Wallace, M. (1991). Training foreign language teachers: A reflective approach. Cambridge: Cambridge University Press.

[45] Wenger, E. (2003). Communities of practice. An essay distributed to participants in the Fall 2003 California Council of Teacher Education Conference, October 30-November 1, Shelter Point Hotel, San Diego.

[46] Wenger, E. (1998). Communities of practice: Learning, meaning, and identity. New York, NY: Cambridge University Press.

[47] Zeichner, K. M., Liston, D. P. (1996). Reflective teaching: an introduction. Mahwah: Lawrence Erlbaum Associates. 